\title{
Aid Volatility and Social Performance in Microfinance
}

\section{Bert D'Espallier, Marek Hudon and Ariane Szafarz}

Uncertainty makes objectives harder to reach. This paper examines whether uncertainty in subsidies leads to mission drift in microfinance institutions (MFIs). Using a worldwide sample of 1,151 MFIs active in 104 countries, we find that interest rates increase with aid volatility while average loan size is inversely related to aid volatility. These results suggest that MFIs consider average loan size as a signaling device for commitment to their social mission, but use interest rates as an adjustment variable to cope with uncertainty. The policy prescription to donor agencies wishing to curtail the rise in interest rates is to deliver subsidies predictably and transparently.

JEL Classifications: F35, G21, G28, O54, O57

Keywords: Microfinance, subsidies, mission drift, average loan size, interest rate.

\section{CEB Working Paper N 16/015}

February 2016 


\title{
Aid Volatility and Social Performance in Microfinance*
}

\author{
Bert D'Espallier \\ KU Leuven, and CERMi \\ bert.despallier@kuleuven.be \\ Marek Hudon** \\ Université Libre de Bruxelles (ULB), SBS-EM, CEB, and CERMi \\ mhudon@ulb.ac.be \\ Ariane Szafarz \\ Université Libre de Bruxelles (ULB), SBS-EM, CEB and CERMi \\ aszafarz@ulb.ac.be
}

February 2016

Forthcoming in Nonprofit and Voluntary Sector Quarterly

JEL Classifications: F35, G21, G28, O54, O57

Keywords: Microfinance, subsidies, mission drift, average loan size, interest rate.

* We wish to express our gratitude to Beatriz Armendariz and Jonathan Morduch for fruitful discussions on subsidies and mission drift in microfinance institutions. This paper largely benefited from these discussions. The research has been carried out in the framework of an "Interuniversity Attraction Pole" on social enterprise, funded by the Belgian Science Policy Office. We also thank the Belgian Fonds de la Recherche Scientifique (F.R.S.-FNRS) for financial support.

** Corresponding Author 


\begin{abstract}
Uncertainty makes objectives harder to reach. This paper examines whether uncertainty in subsidies leads to mission drift in microfinance institutions (MFIs). Using a worldwide sample of 1,151 MFIs active in 104 countries, we find that interest rates increase with aid volatility while average loan size is inversely related to aid volatility. These results suggest that MFIs consider average loan size as a signaling device for commitment to their social mission, but use interest rates as an adjustment variable to cope with uncertainty. The policy prescription to donor agencies wishing to curtail the rise in interest rates is to deliver subsidies predictably and transparently.
\end{abstract}




\section{Introduction}

Nonprofit microfinance organizations typically rely on subsidies and donations to finance their operations. The support of donors is often key to the sustainability of these organizations. In particular, donors have a significant influence on the balance between financial and social objectives. For example, in the 1970's many US nonprofit organizations became increasingly commercial due to tougher budget constraints imposed by donor agencies (Defourny and Nyssens, 2010). Donors can have a negative impact on social outcomes, not only by reducing their contributions but also by imposing uncertainty about aid, which is detrimental. This paper studies the impact of aid uncertainty on the social performance of microfinance institutions (MFIs). Based on extensive empirical work, our results suggest that MFIs can meet their poverty alleviation objectives more easily if the volume and schedule of subsidies received from donor agencies are certain, or at least foreseeable.

The microfinance sector is well suited to this analysis because variables used to measure both financial and social performances have been recorded for more than ten years. MFIs worldwide have benefitted from millions of dollars in subsidies from local governments, multilateral aid agencies and, more recently, socially responsible investors. Subsidies have helped to provide financial access for approximately 210 million people (Reed, 2015). Nevertheless, the effect of subsidized microfinance on poverty alleviation remains controversial.

This paper examines whether uncertainty in subsidies leads to mission drift in MFIs. From a macro perspective, Neanidi and Varvarigos (2009) state that aid volatility can 
significantly hamper economic growth. Uncertainty about aid tends to be much higher than uncertainty about domestic tax revenues (Bulir and Hamann, 2008) and other macroeconomic variables, such as GDP (Fielding and Mavrotas, 2008). Aid volatility increases with political risks in recipient countries (Hudson and Mosley, 2006). Aid disbursements are hardly predictable and predominantly based on donors' commitments (Bulir \& Hamann, 2003). Hudson and Mosley (2006) argue that measures which enhance trust between donor agencies and recipients, and those which increase the degree of competition among donors, reduce the volatility of aid without reducing its effectiveness. Lensink and Morrissey (2000) find that the level of aid is not significantly related to economic growth whereas aid uncertainty is inversely related to it. Their macro-level survey concluded that aid is less effective when volatile. Our findings at the micro level suggest similar results. To maximize their impact, donor agencies must clearly specify the rules, volume and timing of disbursements.

Generally speaking, volatility is a problem because it makes objectives harder to reach. In microfinance more specifically, the uncertain nature of donors' subsidies puts pressure on the management of MFIs (Balkenhol, 2011). Indeed, an overwhelming majority of MFIs are net recipients of subsidies from international donor agencies. ${ }^{1}$ Attempts to build long-term strategic plans with short-term subsidy commitments that are frequently renegotiated are the everyday challenges facing many MFI directors. There is a substantial literature suggesting that subsidy volatility may affect the behavior of socially-oriented or nonprofit organizations (Horne et al., 2005). Consequently, subsidy uncertainty may hinder an MFI in fulfilling its social mission. In other words, subsidy uncertainty might lead 
organizations to drift away from their original mission, a phenomenon known as "mission drift.”

Mission drift is a risk for all types of social enterprise and nonprofit organizations (Jones, 2007). Most donors associate microfinance mission drift with increasing average loan size. Undeniably, granting larger loans correlates to attracting wealthier clients who can afford to repay a substantial amount of money. Granting larger loans could therefore signal a shift away from a poor clientele requesting very small loans. However, Armendáriz and Szafarz (2011) emphasize that larger loans may also result from cross-subsidization, which means charging relatively higher rates to wealthier borrowers to compensate for the lower rates charged to poorer ones. This can be done, for instance, by charging the same interest rate for small and larger loans, even though the latter are less costly for the borrower. In addition, loan size is but one of two social characteristics that render credit affordable to the poor; the other is the interest rate charged. Owing to the low degree of competition in many developing countries (Mersland, 2009), MFIs manage to set rates in the same way as monopolistic banks. As a consequence, this paper works under the assumption that loan size and interest rate are complementary variables used by MFIs to cope with uncertainty and absorb shocks. Accordingly, we scrutinize two dimensions of microfinance mission drift: granting larger loans and charging higher interest.

Placing loan size and interest rates on an equal footing departs from the standard approach. Microfinance literature tends to concentrate on loan size, scaled by per-capita gross national income. Average loan size is the common proxy for the clientele's poverty level, also referred to as depth of outreach (Cull et al., 2009; Galema et al., 2012). Donor organizations routinely use loan size as a measure of social performance (CGAP, 2009). In 
contrast, the interest rate has only recently emerged as a relevant component of the social mission of MFIs. The rate charged is not directly observable by donors and investors; the best available proxy is the portfolio yield. Awareness of interest rates arose from publicized accusations that many MFIs, including highly profitable ones such as Banco Compartamos, charge usury rates. While direct intervention by donors in pricing is controversial, there is a consensus that subsidies can indirectly lower rates of interest through efficiency gains (Balkenhol, 2007). Meanwhile, most donors consider that interest rates should be high enough to make MFIs self-sufficient, at least in the long run. For instance, experts from the Consultative Group to Assist the Poor (CGAP), the largest consortium of donor agencies, believe that subsidies should be used to strengthen MFIs instead of being transferred to clients through low interest rates (Helms, 2006). In short, donors pay closer attention to loan size than to interest rates.

Donors’ asymmetric concern for loan size and interest rates leads us to predict that subsidized MFIs would use rates, rather than size, as an adjustment variable to cope with uncertainty. To test this prediction, we use data collected from rating agencies. We account for potential endogeneity by estimating a bivariate model where average loan size and interest rates are explained simultaneously by subsidy uncertainty in addition to MFI-level controls. The empirical results are in line with our expectations. We find a positive relationship between subsidy uncertainty and interest rates. In contrast, loan size is inversely related to subsidy uncertainty, although the incremental explanatory power of adding subsidy uncertainty as a regressor is limited in loan size regressions. In sum, subsidy uncertainty does not trigger mission drift if defined in terms of depth of outreach, but it does if mission drift is defined in the broader sense of worsening credit conditions for the poor. 
The remainder of the paper is structured as follows. Section 2 briefly reviews the literature on subsidies in microfinance. Section 3 describes the data and presents the empirical results. Section 4 concludes.

\section{Subsidies to Microfinance}

Microfinance and subsidies are deeply intricate. Microfinance emerged in the mid-1970s thanks to the generosity of visionary donor agencies such as the International Fund for Agricultural Development, Deutsche Gesellschaft für Technische Zusammenarbeit in Asia, and the United States Agency for International Development in Latin America. However, subsidized microfinance is questioned for at least two reasons. First, recent impact surveys yield mixed results on various dimensions of poverty alleviation, such as income generation and women's empowerment (Garikipati, 2008; Banerjee and Duflo, 2011; Agier and Szafarz, 2013 and 2013a). Second, subsidized investment funds have been accused of crowding out both private actors and savings mobilization efforts by offering money to MFIs that can afford commercial rates.

In contrast, Armendáriz and Morduch (2010) provide a theoretical argument in favor of subsidization. The authors state that when the production function is not "conveniently" concave, capital will not flow naturally from rich to poor as standard neo-classical theory predicts. Loans will instead be granted to wealthier individuals, because they are likely to have other production inputs (e.g., business savvy or higher levels of human capital) and because, relative to the poor, they can earn higher returns on capital through economies of 
scale. The wealthy demand large loans, which they manage to invest at much higher rates of return compared with those of the poor, whose businesses are small. ${ }^{2}$

Management literature provides arguments explaining why grantees would adjust their behaviors to donors' objectives. Any organization can be conceptualized as a key decision maker that can be influenced by other actors who may "negotiate a compromise between different interests, which in turn provide the basis for an instrumental rational choice based on knowledge of alternatives and consequences” (Christensen et al., 2008, p. 10). In the case of microfinance, the relevant compromise can be viewed as an MFI's rational response to the interests expressed by its donors, who are powerful stakeholders.

DiMaggio and Powell (1983) conceptualize similarity in organizational processes and structures as isomorphism. According to this view, organizations change more under the pressure of external constituencies rather than for technical needs. For example, the alignment of MFIs with their funders can be theorized as coercive isomorphism, which means that similarity in processes results from the pressure exerted by one organization on the other (Verbruggen et al., 2010). In the case of nonprofit organizations, coercive isomorphism is often related to dependence on resources.

Microfinance donors may also exert influence without explicit pressure. In mimetic isomorphism, organizations deal with uncertainty or ambiguity by imitating other organizations (Haveman, 1993). In particular, nonprofit organizations modify their business models in order to gain more credibility with private and public funders (DiMaggio and Powell, 1983; Abzug and Galaskiewicz, 2001), 
According to Christensen et al. (2008), donors' influence can also be legitimized by managerial incompetence or a lack of relevant information. Managers in charge of decisionmaking are often confronted with a wide range of interrelated variables. Hence, they might rationally adopt simple decision rules (Kahneman and Tversky, 1974). As a matter of fact, the managing of multi-objective hybrid organizations is particularly complex (Labie, 2001). For instance, MFIs have the dual mission of poverty alleviation and financial sustainability. The collecting of data and tracking of social objectives is notoriously difficult, which also complicates donors’ monitoring (Hudon and Sandberg, 2013).

Public funding bodies develop two main strategies to influence their grantees: incentives and regulatory rules. Incentives are well suited to address issues that cannot be fully stipulated in legal contracts (Shapira, 2002). Typical incentives set performance criteria to be fulfilled for the disbursement of subsidy tranches or to gain access to funds in the future. While incentives are mostly used to align the interests of corporate owners and managers, they have been increasingly used by donors to influence their grantees.

Empirical evidence on the social impact of subsidies in microfinance is scarce. Notable exceptions include recent work by Hudon (2010), and Hudon and Traça (2011). Their focus is on the impact of subsidies on managerial efficiency. Hudon (2010) finds that subsidies do not impact positively on management quality. Similarly, Hudon and Traça (2011) find that subsidies have a marginally positive impact on financial efficiency. In contrast, Caudill et al. (2009) find that lower subsidies are associated with higher cost reduction over time. 
Morduch (1999a) estimates that subsidies to the Grameen Bank in Bangladesh amounted to USD 175 million in the 1985-1996 period alone. In Latin America, BancoSol in Bolivia and Banco Compartamos in Mexico also benefitted from subsidies (GonzálezVega et al, 1996). BancoSol used subsidies to transform itself from an NGO into a full commercial bank. Cull et al. (2007) show that group lending MFIs, whether solidarity groups such as Grameen-most prevalent in Asia-or village banking institutions-most common in Latin America-are net recipients of a disproportionate amount of subsidies relative to those accruing to MFIs using individual lending methodologies. NGOs unsurprisingly receive a large amount of subsidies compared to commercial banks.

When the microfinance movement gained momentum in the 1980s, donors were urged to implement so-called "smart subsidies” (Armendáriz and Morduch, 2010). Such subsidies, it was contended, ought to meet three criteria by being transparent, rule-bound, and, most importantly, time-limited. Donors have therefore worked increasingly with targets and key performance indicators to improve their efficiency. Donors were encouraged to focus on subsidizing start-up expenses, institutional capacity building, and product development, with an eye to designing an exit strategy within a particular timeframe. In the mid-2000s the commercialization of MFIs prompted researchers to revisit the subsidy design literature. It was recognized that competition in microfinance could be harmful due to the risk of overindebtedness (Schicks, 2012).

In sum, subsidization to microfinance is still a controversial issue. Undeniably, subsidies support MFIs in their efforts to offer financial services to the poor, who request small loans involving high operational costs (Copestake, 2007). In return, donors expect MFIs to reach the so-called "double bottom line" objective: offering affordable financial 
services to poor people while achieving financial self-sustainability. The problem, then, is how donors can make sure that subsidized MFIs will meet their double bottom line and avoid mission drift (Armendáriz et al., 2011). In fact, the overall impact of subsidies on social performances remains largely unknown. The empirical analysis in the next section is intended to bridge that gap.

\section{Data and Results}

Our empirical analysis aims to test whether there is a relation between subsidy uncertainty and social performance. We use a dataset provided by the Microfinance Information Exchange (MixMarket). MixMarket data is used in many articles (Ahlin et al., 2010; Cull et al., 2009; Hermes et al., 2011) and includes audited financial statements in addition to general information relating to the institutions. Its major strength lies in the large number of MFIs included in the dataset. A limitation is that data are voluntarily submitted by the MFIs, which may lead to a self-selection bias. The dataset includes information on 1,151 MFIs

active in 104 countries $^{3}$ extracted from annual accounting statements. Importantly, the number of years of available subsidy data per MFI ranges from 2 to 16, with a median of 8 , and in most cases falls between 6 and 10 .

The dataset contains a wide variety of MFIs (see Appendix 1): 47\% are NGOs, 14\% are cooperatives, $6 \%$ are banks, and $31 \%$ are non-banking financial institution (an intermediate status between unregulated NGOs and fully-fledged banks). The remaining 2\% have another status, such as state bank or regional rural bank. To check the 
representativeness of our sample we compare some basic statistics with those from the 890 MFIs included in the 17th MicroBanking Bulletin (MBB, 2008), and we obtain similar figures. ${ }^{4}$

Table 1 presents descriptive statistics. The median MFI has been in operation for 9 years. Its total outstanding loan portfolio is USD 9,730,000. Its average loan size is USD 782. Similarly to Cull et al. (2009), we use portfolio yield in real terms to proxy the interest rate $^{5}$. Portfolio yield is calculated as the ratio of interests paid on loans divided by total loan portfolio corrected for inflation.

To measure subsidy (as a \%) we take information from the income statement (annual level of subsidies in USD relative to total assets) as well as the balance sheet (donated equity in USD relative to total equity) to account for the different kinds of subsidies that MFIs receive. The 'donated part' of equity, which is used, for instance, in Hudon and Traça (2011), measures the historical subsidies received whereas the annual subsidy received extracted from the annual income statement focuses more closely on the current yearly subsidies received. We provide analyses in terms of both subsidy measures. As expected, the vast majority of MFIs in our sample depend heavily on subsidies. The median MFI enjoys a roughly $17 \%$ subsidization rate in terms of donated equity and the average annual subsidy received is $4.6 \%$ of total assets.

$<$ Insert Table 1 here >

We measure subsidy uncertainty by the standard deviation of the subsidy. Since the subsidy is a relative measure (whether in terms of donated equity or annual subsidies), the standard deviation becomes comparable across MFIs. This variable subsidy uncertainty 
ranges from $0 \%$ to $19 \%$, with a mean value of $4.5 \%$. The closer the standard deviation of the subsidization rate to zero, the smaller the subsidy fluctuations. For instance, unsubsidized MFIs, as well as MFIs with a constant share of donated equity, have zero subsidy uncertainty. Conversely, MFIs with large standard deviations are subject to high subsidy fluctuations over the observed sample period.

Admittedly, unconditional standard deviations are rough proxies of expected volatility for future subsidies. They are computed over the entire sample period, and are therefore not usable as such by MFIs. However, we have no option but to rely on some steady-state assumptions on subsidy uncertainty and to interpret our measure as the indicator used by MFIs when deciding on the need for precautionary savings.

In addition, this method raises the possibility of reverse causality. An MFI’s decisionmaking can indeed cause subsidies to fluctuate. Nevertheless, the risk of reverse causality is lower for subsidy uncertainty than for the subsidies themselves. Donors typically adapt their subsidies to the development of the MFI, but it is unlikely that they purposely impose uncertainty on the institution they intend to support. In addition, controlling for subsidies helps separate the effect of subsidy uncertainty on mission drift from the direct effect of the subsidies themselves, which may be endogenous. Even so, we subsequently interpret our empirical results in terms of linkages rather than implications.

As discussed above, we capture mission drift through two variables. The first, average loan size, is intended to capture the move from costly poor clients to profitable wealthier ones. MFIs typically grant very small loans to poor borrowers and relatively larger loans to those that are wealthier. A higher loan size would thus suggest that the MFI is shifting from 
assisting the poor to serving the better-off. In line with the literature, average loan size is scaled by per-capita GNI to draw meaningful cross-country comparisons. It should be noted that although this variable is widely used, many scholars have expressed concerns about its validity as a measure for social performance. First, larger average loans could reflect that a part of the loan portfolio is scaled up, and that larger loans are being complemented with smaller loans (Armendàriz and Szafarz, 2011). Additionally, as Christen (2001) suggests, the difference in average loan size might mean either targeting less poor clients or providing larger loans to the clientele i.e. progressive lending. For these reasons, the relation between subsidies and average loan size should be interpreted with caution.

The second variable associated with mission drift is the interest rate charged. Higher interest rates would signal lower social concern (Ghosh and Van Tassel, 2011). Arguably, wealthier clients can afford to pay more for potentially riskier loans, whereas the poor cannot. Clientele shifts aside, the-sometime usurious-levels of interest rates charged by MFIs are often criticized as demonstrating the "ugly side" of an industry drifting away from its social mission (Hudon and Sandberg, 2013).

In practice, donors and practitioners routinely use average loan size as the main indicator for assessing social performance. Their rationale is that larger loans are likely to exclude the poorer segments of the population (Cull et al., 2007; Mersland and Strøm, 2009). However, the perception of interest rates as a core part of the microfinance mission is gaining momentum. Yunus (2007, p. 1) considers that high IRC indicates mission drift. His argument stems from the requirement that "a true microcredit organization must keep its interest rate as close to the cost-of-funds as possible”. 
In fact, average loan size (ALS) and interest rate charged (IRC) are two complementary variables MFIs use when designing their credit conditions. As a result, ALS and IRC are jointly determined. In our data, the univariate sample correlation between IRC and ALS is -0.25 . Therefore, rather than separately analyzing the relationship between subsidy uncertainty and each of these two variables, we estimate a bivariate system. ${ }^{1}$ This approach acknowledges the endogeneity of ALS and IRC by allowing the error term of the two equations to be correlated.

Specifically we estimate the following system:

$\left\{\begin{array}{l}I R C_{i, t}=\beta_{0}+\beta_{1} \text { subsidy uncertainty }_{i}+\beta^{\prime} \text { controls }+\varphi_{i, t} \\ A L S_{i, t}=\gamma_{0}+\gamma_{1} \text { subsidy uncertainty }+\gamma^{\prime} \text { controls }+\omega_{i, t}\end{array}\right.$

where parameters $\beta_{0}, \beta_{1}$, and $\beta^{\prime}$ are estimated simultaneously with $\gamma_{0}, \gamma_{1}$, and $\gamma^{\prime}$, and correlation between $\varphi_{i, t}$ and $\omega_{i, t}$ is allowed within the system.

We use the following control variables: MFI type ${ }^{6}$, age, and size; a dummy indicating whether the MFI offers savings in addition to credit; and portfolio-at-risk (i.e. the proportion of loans repaid late). We also include the level of subsidies in order to clearly disentangle subsidy uncertainty from its deterministic counterpart. In addition, we consider regressions with or without time and regional dummies. ${ }^{7}$

The parameters in Eq. (1) are estimated using the seemingly unrelated regression (SUR) procedure developed in Zellner (1963). In all specifications, the Breusch-Pagan test

\footnotetext{
${ }^{1}$ An (unreported) robustness check using univariate equations confirms the results obtained with our bivariate system.
} 
statistic for independence is significant at the $5 \%$ level, confirming that IRC and ALS are simultaneously determined.

$<$ Insert Table 2 here $>$

Table 2 reports our baseline regression results for the IRC-ALS system. The first three columns show what happens if regional dummies and time dummies are subsequently accounted for. Column 4 reports the system without subsidy uncertainty to assess the changes in the overall quality of the system when subsidy uncertainty is added. In each column, we also report the $\mathrm{R}^{2}$ of each individual equation and the increase in $\mathrm{R}^{2}$ compared to the benchmark model without subsidy uncertainty from column 4 .

The results show that subsidy uncertainty is positive in all IRC equations, and negative in all ALS equations within the simultaneously estimated system. Furthermore, adding subsidy uncertainty significantly contributes to the explanatory power of IRC regressions, whereas the contribution for ALS regressions is limited.

It follows that higher subsidy uncertainty is significantly associated with higher IRC, but not with higher ALS. This means that MFIs faced with greater uncertainty increase their interest rates charged to clients, rather than augmenting the size of the loans. In contract, the level of subsidies reduces ALS but its effect on IRC is insignificant (see column 4). Subsidies have thus a twin impact on social indicators: a direct one on ALS and an indirect one, channeled by uncertainty, on IRC.

Our results confirm those of Hudon and Traça (2006), who find that subsidies lower ALS. In the same vein, Cull et al. (2009) state that donors and MFI managers share the same objectives regarding ALS. Managers are keen to target poor clients, and subsidies 
help them cover the heavy operating expenses related to the granting of small loans. This argument may explain why subsidy uncertainty negatively affects ALS.

On the other hand, our results suggest that MFIs use IRC as an adjustment variable in instances of uncertainty. To avoid donor dissatisfaction, MFIs prefer to increase IRC rather than ALS. Using IRC allows MFIs to cope with external shocks such as those stemming from variations in subsidies. A similar effect is reported by Dehejia et al. (2012) having studied a Bangladeshi MFI that increased IRC to cope with the consequences of a natural disaster.

For each system estimated, we report the F-test for the null hypothesis that both coefficients of subsidy uncertainty are 'jointly' insignificant within the system. In all specifications the test rejects the null hypothesis, suggesting a significantly positive relationship between subsidy uncertainty and social performance within the overall system designed to take into account the interdependence between ALS and ICR. Looking at the $\mathrm{R}^{2}$ of the individual equations as well as the increases in $\mathrm{R}^{2}$ from the benchmark model, we see that adding subsidy uncertainty adds between $2.3 \%$ and $2.7 \%$ of explanatory power to the IRC equations and virtually nothing (between $0.5 \%$ and $0.9 \%$ ) to the ALS. This suggests IRC is much more affected by subsidy uncertainty than ALS.

The parameters on the control variables also deliver interesting insights. First, the regressions confirm that MFIs depending more heavily on subsidies tend to grant smaller loans (D’Espallier et al., 2013a). Second, MFIs that offer savings in addition to credit tend to provide larger loans. Third, MFI size (proxied by the natural logarithm of total assets) matters. Larger MFIs offer larger loans and charge lower interest rates. Lastly, NGOs offer 
smaller loans, but there is no link between MFI type and IRC. This contrasts with previous findings showing that IRC is affected by the type of MFI (Dorfleitner et al., 2013; Roberts, 2013). Our results may indicate that failing to account for the dependency between IRC and ALS could bring an omitted-variable bias into single equation IRC regression. This conjecture deserves further investigation.

Next, we run several robustness checks. First, we analyze whether our results are driven by using the standard deviation to measure subsidy uncertainty. Since standard deviations of subsidies are computed on a limited number of observations per MFI, our results might be plagued by measurement error. Accordingly, in Table 3 we use the spread of subsidy as a percentage of total assets as an alternative measure for subsidy uncertainty. The spread is the difference between the maximum and minimum level of subsidy received in the sample period. It is less sensitive than the standard deviation to the number of observations per MFI. In Table 4, we only include those MFIs for which we have at least 5 years of data. This sub-sample is made up of 752 MFIs representing $65 \%$ of our original sample omitting those MFIs with few years of data.

\section{$<$ Insert Tables 3 and 4 here $>$}

Tables 3 and 4 show that these modifications leave the baseline results on subsidy uncertainty unchanged. Specifically, subsidy uncertainty has a significantly positive impact on the IRC, and a negative impact on ALS. The negative impact of the level of the subsidy on ALS is also confirmed (column 4 in both tables). The Breusch-Pagan tests reject the null hypothesis that the equations of the system are unrelated. The joint F-tests indicate that the relationship between social performance and subsidy uncertainty is significant throughout 
the system. Again there is a considerable increase in the $\mathrm{R}^{2}$ of the IRC regressions in the order of 3.6\%, and a negligible increase in $\mathrm{R}^{2}$ in ALS regressions.

$$
<\text { Insert Table } 5 \text { here > }
$$

Second, we re-estimate the system using donated equity as a percentage of total equity as our subsidy measure and the standard deviation on this relative subsidy measure as our proxy for uncertainty. Results are reported in Table 5. As mentioned earlier, donated equity tends to emphasize more the historical subsidies received whereas yearly subsidies from the income statement reflect current subsidies received. Again, the same results emerge. Higher uncertainty in (\%) donated equity is associated with higher IRC and lower ALS. A higher level of (\%) donated equity is associated with smaller loans. The model statistics are satisfactory and indicate the interdependence of ALS and IRC and a considerable increase in $\mathrm{R}^{2}$ in IRC regressions.

$$
<\text { Insert Table } 6 \text { here }>
$$

Third, in line with Markowitz (1991), we compute the downside variation in subsidy to analyze whether MFIs might be more concerned by under-subsidization i.e. downward fluctuations in their subsidy, than by over-subsidization i.e. upward fluctuations. Technically, we assign the median values of the share of subsidy to all observations above the median MFI-value and then recalculate the standard deviation for each MFI. This computed measure assigns a greater importance to fluctuations below the median MFI-value and neglects fluctuations above the median level. We then look at the influence of this downside variation in the IRC-ALS system. The results reported in Table 6 show that the downside deviation has a significant positive influence on IRC and adds to the explanatory 
power of the IRC-regressions. They thereby confirm the negative influence of subsidy uncertainty on social performance.

From the estimated coefficients, it is, however, difficult to see whether the downside deviation affects IRC to a greater degree than the bilateral measure of uncertainty used previously. To test this hypothesis, we re-estimate a bivariate model with interaction. The subsidy uncertainty is interacted with a dummy that equals 1 for the $30 \%$ of MFIs with the highest downside variation. The results (not reported here) fail to detect any significant interaction term. We thus reject the hypothesis that the influence of subsidy uncertainty is stronger for MFIs that face higher downside fluctuations.

Finally, a number of additional non-reported checks were performed. They include split-sample regressions for nonprofit MFIs (NGOs and coops), which show that subsidy uncertainty positively influences IRC in all categories. Next, including macro-economic control variables $^{8}$ in the model does not alter the results; nor do they improve any of the model statistics. Finally, separate single equation regressions are used to test whether subsidy uncertainty has a distinctive effect on operational costs, i.e. whether MFIs facing more uncertainty would be more (or less) cost-efficient. The lack of any significant result suggests that uncertainty is managed on the income side of the MFI, not on the cost side. This could reflect the fact that MFIs enjoy considerable freedom in setting interest rates.

Overall, our estimations confirm that MFIs are sensitive to subsidy uncertainty, a point never before raised in the literature. Our econometric approach investigates the relationship between variations in subsidization and MFIs' social missions in terms of ALS and IRC, taking into account the natural interdependence between these two variables. It 
shows that higher subsidy uncertainty leads to mission drift captured through an increase in IRC. In contrast, ALS is negatively affected by subsidy uncertainty, although the incremental explanatory power of adding subsidy uncertainty to ALS-regressions is limited. The results lend credence to our prediction that MFIs care more about ALS than about IRC. We view this as evidence of the impact of donors on the management of MFIs. In addition, our findings may help when designing efficient subsidies. Stable and foreseeable subsidies are more efficient than variable ones, since uncertainty pushes MFIs to charge higher interest rates, all other things being equal.

\section{Concluding Remarks}

The social mission of microfinance is to provide affordable financial services to the poor and help them escape poverty. Recent impact surveys have challenged the impact of microfinance on poverty reduction, opening a debate about whether or not donors should keep subsidizing the microfinance sector. However, the literature suffers from a lack of rigorous assessment of the precise role played by subsidies. With this paper we have moved the debate forward. We find that volatility in subsidies triggers mission drift. To deal with external shocks, such as subsidy volatility, MFIs tend to use the interest rate as an adjustment variable while average loan size is not affected.

Since our results suggest that subsidy uncertainty has a detrimental impact on interest rate levels, the policy prescription to donors and aid agencies wishing to curtail interest rate rises is to deliver subsidies predictably and transparently. Such donors and agencies should re-design subsidy delivery by making credible commitments. Our results echo, at the micro 
level, the conclusion reached by Lensink and Morrissey (2000) that the volatility of aid reduces its effectiveness. In both cases, enhancing the quality of donations by reducing uncertainty is seen to be beneficial to the very purpose of those donations.

Our analysis focuses on the uncertainty associated with subsidies. However, this is only one source of risk for managers of MFIs. Other sources include natural disasters, fraud, and financial risks. Surprisingly, except for the management of portfolio quality (Mersland and Strøm, 2009, D’Espallier et al., 2011), the literature is silent on the issues arising from risk management in microfinance and the ways in which it interferes with social performance. This topic offers promising avenues for further research.

Microfinance literature tends to view mission drift as a deterministic phenomenon where social performance deteriorates when MFIs evolve toward commercialization (Copestake, 2007; Ghosh and Van Tassel, 2008). Our conjecture is that mission drift could also be caused by fear that sustainability will not be reached within a particular timeframe set ex ante by donors. By not establishing a clear, credible sustainability time limit, donors might create a moral hazard problem. Moreover, to ensure the long-term funding of their operations, MFIs may feel compelled to borrow on international financial markets. This could eventually accelerate the trend towards commercialization in microfinance.

Our approach is innovative, but it can undoubtedly be improved. First, subsidy volatility may be proxied by various channels. Here, we have used standard deviations of income statement and balance sheet subsidies scaled respectively by total assets and total equity. Unconditional standard deviations are rough proxies of expected volatility for future subsidies and therefore not usable as such by MFIs. Second, future research should be 
directed at identifying profitable versus unprofitable lending, and towards singling out the impact of subsidy uncertainty on costly loans. This would require better data on loan costs and other elements, such as compulsory savings, loan products with different terms, and delinquency. More generally, empirical research using expanded data for a longer period is needed. We emphasize these data limitations in the hope that donors and MFIs will take them on board and move empirical research agendas forward.

Economists tend to analyze international aid flows at the country level. In microfinance, however, aid is given to local institutions, either directly or channeled through international NGOs. Aid uncertainty is recognized as a nuisance at the macro level but little is known at the micro level. By studying the impact of aid uncertainty on the management practices of grantees, this paper has shed light on the micro level. This is especially relevant in the current context in which aid from developed countries has been compromised in the aftermath of the 2007-2008 economic crisis. With subsidies becoming increasingly scarce, they need to be designed efficiently. 


\section{References}

Abzug, R. \& J. Galaskiewicz (2001), “Nonprofit boards: Crucibles of expertise or symbols of local identities?” Nonprofit and Voluntary Sector Quarterly 30, 51-73.

Agier, I. \& A. Szafarz (2013), "Subjectivity in credit allocation to micro-entrepreneurs: Evidence from Brazil,” Small Business Economics 41, 263-275.

Agier, I., \& A. Szafarz (2013a), "Microfinance and gender: Is there a glass ceiling on loan size?” World Development 42, 165-181.

Armendáriz, B., B. D’Espallier, M. Hudon \& A. Szafarz (2011), “Subsidy uncertainty and microfinance mission drift,” Working Paper CEB 11-014, ULB.

Armendáriz B. \& J. Morduch (2010), The Economics of Microfinance (2 ${ }^{\text {nd }}$ Edition), Cambridge, MA: MIT Press.

Armendáriz, B. \& A. Szafarz (2011), “On mission drift in microfinance institutions,” in B. Armendáriz \& M. Labie (Eds), The Handbook of Microfinance, London-Singapore: World Scientific Publishing, 341-366.

Banerjee, A. \& E. Duflo (2011), Poor Economics, New York: Foreign Affairs.

Beisland, L. \& R. Mersland (2012), "An analysis of the drivers of microfinance rating assessments,” Nonprofit and Voluntary Sector Quarterly 41, 2, 213-231.

Beisland, L. \& R. Mersland (2014), "Earnings quality in nonprofit versus for-profit organizations: Evidence from the microfinance industry”, Nonprofit and Voluntary Sector Quarterly 43, 4, 652-671.

Bhatt, N. \& S.-Y. Tang (2001), "Delivering microfinance in developing countries: Controversies and policy perspectives,” Policy Studies Journal 29, 319-333. 
Bulir, A. \& A.J. Hamann (2003), “Aid volatility: An empirical assessment,” IMF Staff Papers 50, 1, 64-89.

Bulir, A. \& A.J. Hamann (2008), "Volatility of development aid: From the frying pan into the fire?” World Development 36, 10, 2048-2066.

Caudill, S., D. Gropper, \& V. Hartarska (2009), "Which microfinance institutions are becoming more cost-effective with time? Evidence from a mixture model,” Journal of Money, Credit, and Banking 41, 4, 651-672.

Christensen, T., P. Lægreid, P.G. Roness, \& K.A. Røvik (2008), Organization Theory and the Public Sector. London: Routledge.

Consultative Group to Assist the Poor (CGAP) (2009), Measuring Results of Microfinance Institutions. Minimum Indicators That Donors and Investors Should Track, CGAP, The World Bank Group.

Copestake, J. (2007), "Mainstreaming microfinance: Social performance management or mission drift?” World Development 35, 1721-1738.

Cull, R., A. Demirgüç-Kunt, \& J. Morduch (2007), "Financial performance and outreach: A global analysis of leading microbanks,” Economic Journal 117, 107-133.

Cull, R., A. Demirguc-Kunt, \& J. Morduch (2009) "Microfinance meets the market," Journal of Economic Perspectives 23, 167-192.

Defourny, J. \& M. Nyssens (2010), "Conceptions of social enterprise and social entrepreneurship in Europe and the United States: Convergences and divergences,” Journal of Social Entrepreneurship 1, 1, 32-53.

Dehejia, R, H. Montgomery, \& J. Morduch (2012), “Do interest rates matter? Credit demand in the Dhaka slums,” Journal of Development Economics 97, 437-449. 
D’Espallier, B., I. Guérin, \& R. Mersland (2011), “Women and repayment in microfinance: A global analysis,” World Development 39, 758-772.

D'Espallier, B., I. Guérin, \& R. Mersland (2013), “Focus on women in microfinance institutions,” Journal of Development Studies 49, 589-608.

D’Espallier, B., M. Hudon, \& A. Szafarz (2013), “Unsubsidized microfinance institutions,” Economics Letters 120, 174-176.

DiMaggio, P.J. \& W. Powell (1983), “The iron cage revisited: Institutional isomorphism and collective rationality in organizational fields,” American Sociological Review 48, 147-160.

Dorfleitner, G., M. Leidl, C. Priberny, \& J. von Mosch (2013), "What determines microcredit interest rates?” Applied Financial Economics 23, 1579-1597.

Dunford, C. (2002), “What's wrong with loan size?” Freedom from Hunger, http://www.ffhtechnical.org/publications/summary/loansize0302.html.

Fielding, D. \& G. Mavrotas (2008), “Aid Volatility and Donor-Recipient Characteristics in 'Difficult Partnership Countries,'” Economica 75, 299, 481-494.

Garikipati, S. (2008), “The impact of lending to women on household vulnerability and women's empowerment,” World Development 36, 2620-2642.

Ghosh S. \& E. Van Tassel (2008), “A model of microfinance and mission drift,” Working Paper, Florida Atlantic University.

Ghosh, S. \& E. Van Tassel (2011), Microfinance and competition for external funding, Economics Letters 112, 2, 168-170. 
González-Vega, C., M. Schreiner, M.R. Meyer, J. Rodríguez-Mesa, \& S. Navajas (1996), "Bancosol: The challenge of growth for microfinance organizations," Working Paper, Ohio State University.

Gutiérrez-Nieto, B., \& C. Serrano-Cinca (2007), "Factors explaining the rating of microfinance institutions,” Nonprofit and Voluntary Sector Quarterly 36, 439-464.

Haveman, H. A. (1993), "Follow the leader: Mimetic isomorphism and entry into new markets,” Administrative Science Quarterly 38, 593-627.

Helms, B. (2006), Access for All, Building Inclusive Financial Systems, CGAP, Washington DC.

Horne, C., J. Johnson, J., \& D. Van Slyke (2005), "Do charitable donors know enough and care enough for government subsidies to affect private giving to nonprofit organizations?” Nonprofit and Voluntary Sector Quarterly 34, 1, 136-149.

Hudon, M. (2010), “Subsidies and financial performances of the microfinance institutions: Does management matter?” Journal of International Development 22, 890-905.

Hudon, M. \& J. Sandberg (2013), “The ethical crisis in microfinance: Issues, findings, and implications,” Business Ethics Quarterly 23, 561-589.

Hudon, M. \& D. Traca (2006), "Subsidies and sustainability in microfinance,” Working Paper CEB 06-020, Université Libre de Bruxelles.

Hudon, M. \& D. Traca (2011), “On the efficiency effects of subsidies in microfinance: An empirical inquiry,” World Development 39, 966-973.

Hudson, J., \& P. Mosley (2008), “Aid volatility, policy and development,” World Development 36, 2082-102. 
Jones, M. (2007), “The multiple sources of mission drift,” Nonprofit and Voluntary Sector Quarterly 36, 299-307.

Labie, M. (2001). “Corporate governance in micro-finance organizations: A long and winding road,” Management Decision, 39(4), 296-301.

Lensink, R. \& O. Morrissey (2000), “Aid instability as a measure of uncertainty and the positive impact of aid on growth,” Journal of Development Studies 36, 31-49.

Markowitz, H. (1991), “Foundations of portfolio theory,” Journal of Finance 46, 469-477.

Mersland, R. (2009), "The cost of ownership in microfinance organizations," World Development 37, 469-478.

Mersland, R. \& R.Ø. Strøm (2009), "Performance and governance in microfinance institutions,” Journal of Banking and Finance 33, 662-669.

Mersland, R. \& R.Ø. Strøm (2010), “Microfinance mission drift?” World Development 38, 28-36.

MicroBanking Bulletin (2008), MFI benchmark data published by Microfinance Information Exchange, online available at:

http://www.themix.org/publications/microbanking-bulletin/2008/08/mfi-benchmarkdatamicrobanking-bulletin-august-2008-issue.

Morduch, J. (1999a), “The microfinance promise,” Journal of Economic Literature 37, 1569-1614.

Morduch, J. (1999b), “The role of subsidies in microfinance: Evidence from the Grameen Bank,” Journal of Development Economics 60, 229-248.

Neanidis, K. \& V. Varvarigos (2009), “The allocation of volatile aid and economic growth: Theory and evidence,” European Journal of Political Economy 25, 447-462. 
Reed, L. (2015), State of the Microcredit Summit Campaign Report 2015, Washington D.C.: Microcredit Summit.

Rosenberg, R., S. Gaul, W. Ford, \& O. Tomilova (2013), “Microcredit interest rates and their determinants: 2004-2011,” in Köhn, D. (Ed.), Microfinance 3.0. Springer: Berlin Heidelberg, 69-104.

Roberts, P. (2013), “The profit orientation of microfinance and effective interest rates,” World Development 41, 120-131.

Schicks, J. (2013) "Microfinance over-indebtedness: Understanding its drivers and challenging the common myths,” Oxford Development Studies 49, 1236-1255.

Shapira, Z. (2002), Organizational Decision Making, Cambridge University Press, Cambridge.

Tchakoute-Tchuigoua, H. (2012), “Active risk management and loan contract terms: Evidence from rated microfinance institutions," Quarterly Review of Economics and Finance 52, 427-437.

Verbruggen, S., J. Christiaens, \& K. Milis (2010). “Can resource dependence and coercive isomorphism explain nonprofit organizations’ compliance with reporting standards?” Nonprofit and Voluntary Sector Quarterly, 40(1), 5-32.

Yunus, M. (2007), “Remarks by Muhammad Yunus, Managing Director, Grameen Bank,” Microcredit Summit E-News 5, 1.

Zellner, A. (1963), “Estimators for seemingly unrelated regression equations: Some exact finite sample results,” Journal of the American Statistical Association 58, 997-992. 


\section{List of Tables}

\section{Table 1. Descriptives}

This table reports the mean, median, standard deviation, minimum, and maximum for the main variables used in this study.

\begin{tabular}{|c|c|c|c|c|c|c|c|}
\hline Variable & Definition & $\mathbf{n}$ & Mean & Median & St. dev. & Min. & Max. \\
\hline$T A$ & total assets in thousands USD & 7,172 & 13,500 & 3,308 & 25,700 & 17.47 & 118,000 \\
\hline Age & number of years in operation & 7,034 & 10.63 & 9.00 & 8.53 & 0 & 109 \\
\hline Equity & total equity in thousands USD & 7,171 & 5,376 & 1,039 & 30,100 & 0.34 & $1,360,000$ \\
\hline$T L P$ & gross loan portfolio in thousands USD & 7,271 & 9,730 & 2,293 & 18,400 & 7.152 & 82,900 \\
\hline subsidy_level & level of subsidies from income statement in USD & 6,956 & 522,119 & 67,961 & $5,279,563$ & 0 & $161,000,000$ \\
\hline subsidy & subsidy as a percentage of total assets & 6,893 & 0.046 & 0.004 & 0.083 & 0 & 0.28 \\
\hline subsidy uncertainty & standard deviation of subsidy & 7,213 & 0.045 & 0.028 & 0.045 & 0 & 0.197 \\
\hline Donated equity_level & donated equity in USD & 3,012 & $1,843,240$ & 521,485 & $5,104,021$ & 2.62 & $130,000,000$ \\
\hline Donated equity & donated equity as a percentage of total equity & 3,054 & 0.287 & 0.177 & 0.303 & 0.000 & 0.991 \\
\hline ALS_level & Average loan size defined as TLP divided by \# loans & 6,879 & 782.07 & 280.59 & 1,370 & 0 & 10,774 \\
\hline ALS & Average loan size defined as TLP divided by \# loans scaled by per capita GNI & 6,678 & 0.52 & 0.26 & 0.64 & 0 & 2.65 \\
\hline IRC & yield on gross porfolio corrected for inflation & 3,974 & 0.24 & 0.21 & 0.14 & 0.03 & 0.59 \\
\hline dumNGO & dummy 1 if MFI is an NGO & 7,140 & 0.47 & 0.00 & 0.50 & 0.00 & 1.00 \\
\hline dumCOOP & dummy 1 if $\mathrm{MFI}$ is a cooperative & 7,140 & 0.14 & 0.00 & 0.34 & 0.00 & 1.00 \\
\hline dumNBFI & dummy 1 if MFI is a non-bank financial institutions & 7,140 & 0.31 & 0.00 & 0.46 & 0.00 & 1.00 \\
\hline dumBANK & dummy 1 if $\mathrm{MFI}$ is a bank & 7,140 & 0.06 & 0.00 & 0.23 & 0.00 & 1.00 \\
\hline dUMOTHER & dummy 1 if MFI is another type (statebank + other) & 7,140 & 0.01 & 0.00 & 0.11 & 0.00 & 1.00 \\
\hline dumNONPROFIT & dummy 1 if MFI is an NGO or cooperative & 7,140 & 0.61 & 1.00 & 0.49 & 0.00 & 1.00 \\
\hline dumSAVING & dummy 1 if MFI has deposit accounts & 6,757 & 0.62 & 1.00 & 0.48 & 0.00 & 1.00 \\
\hline PAR & portfolio at risk (30 days in arrears) & 6,128 & 0.055 & 0.031 & 0.064 & 0.00 & 0.24 \\
\hline
\end{tabular}




\section{Table 2. Joint estimation of interest rate and average loan size}

We jointly regress IRC and ALS on subsidy uncertainty and controls. We use the seemingly unrelated regressions (SUR) procedure. The Breusch-Pagan test asserts the null hypothesis that the residuals of the separate regressions are uncorrelated. We also report a joint F-test that asserts the null hypothesis that the coefficients for subsidy uncertainty are jointly significant. *, ${ }^{* *}$, and ${ }^{* * *}$ denote statistical significance at $10 \%$, $5 \%$, and $1 \%$ level, respectively.

\begin{tabular}{|c|c|c|c|c|c|c|c|c|}
\hline & \multicolumn{2}{|c|}{ (1) } & \multicolumn{2}{|c|}{ (2) } & \multicolumn{2}{|c|}{ (3) } & \multicolumn{2}{|c|}{ (4) } \\
\hline & IRC & ALS & IRC & ALS & IRC & ALS & IRC & ALS \\
\hline Subsidy uncertainty & $\begin{array}{c}0.579 \\
(0.079)^{\star \star \star}\end{array}$ & $\begin{array}{c}-0.871 \\
(0.318)^{\star \star \star}\end{array}$ & $\begin{array}{c}0.614 \\
(0.076)^{\star \star \star}\end{array}$ & $\begin{array}{c}-1.451 \\
(0.297)^{\star \star \star}\end{array}$ & $\begin{array}{c}0.610 \\
(0.075)^{\star \star \star}\end{array}$ & $\begin{array}{l}0.061 \\
-0.083\end{array}$ & - & - \\
\hline \multicolumn{9}{|l|}{ Controls } \\
\hline In(subsidy_level) & $\begin{array}{l}-0.002 \\
(0.002)\end{array}$ & $\begin{array}{c}-0.013 \\
(0.007)^{\star}\end{array}$ & $\begin{array}{l}-0.001 \\
(0.002)\end{array}$ & $\begin{array}{l}-0.007 \\
(0.006)\end{array}$ & $\begin{array}{l}-0.001 \\
(0.002)\end{array}$ & $\begin{array}{c}-0.098 \\
(0.035)^{\star \star \star}\end{array}$ & $\begin{array}{c}0.002 \\
(0.002)\end{array}$ & $\begin{array}{c}-0.018 \\
(0.007)^{\star \star \star}\end{array}$ \\
\hline $\operatorname{lnTA}$ & $\begin{array}{c}-0.018 \\
(0.002)^{\star \star \star}\end{array}$ & $\begin{array}{c}0.104 \\
(0.009)^{\star \star \star}\end{array}$ & $\begin{array}{c}-0.014 \\
(0.002)^{\star \star \star}\end{array}$ & $\begin{array}{c}0.111 \\
(0.009)^{\star \star \star}\end{array}$ & $\begin{array}{c}-0.014 \\
(0.002)^{\star \star \star}\end{array}$ & $\begin{array}{c}0.025 \\
(0.017)^{\star}\end{array}$ & $\begin{array}{c}-0.022 \\
(0.002)^{\star \star \star}\end{array}$ & $\begin{array}{c}0.110 \\
(0.009)^{\star \star \star}\end{array}$ \\
\hline Age & $\begin{array}{l}-0.001 \\
(0.004)\end{array}$ & $\begin{array}{c}-0.008 \\
(0.002)^{\star \star \star}\end{array}$ & $\begin{array}{l}-0.001 \\
(0.001)\end{array}$ & $\begin{array}{c}-0.006 \\
(0.002)^{\star \star \star}\end{array}$ & $\begin{array}{l}-0.001 \\
(0.001)\end{array}$ & $\begin{array}{l}0.004 \\
-0.004\end{array}$ & $\begin{array}{l}-0.001 \\
(0.001)\end{array}$ & $\begin{array}{l}-0.008 \\
(0.002)\end{array}$ \\
\hline dumNONPROFIT & $\begin{array}{c}0.014 \\
(0.007)^{\star}\end{array}$ & $\begin{array}{c}-0.174 \\
(0.028)^{\star \star \star}\end{array}$ & $\begin{array}{c}0.005 \\
(0.007)\end{array}$ & $\begin{array}{c}-0.098 \\
(0.027)^{\star \star \star}\end{array}$ & $\begin{array}{c}0.008 \\
(0.007)\end{array}$ & $\begin{array}{l}-0.036 \\
-0.054\end{array}$ & $\begin{array}{c}0.009 \\
(0.007)\end{array}$ & $\begin{array}{c}-0.167 \\
(0.028)^{\star \star \star}\end{array}$ \\
\hline dumSAVING & $\begin{array}{c}0.002 \\
(0.007)\end{array}$ & $\begin{array}{c}0.059 \\
(0.027)^{\star \star}\end{array}$ & $\begin{array}{c}0.003 \\
(0.007)\end{array}$ & $\begin{array}{l}-0.041 \\
(0.029)\end{array}$ & $\begin{array}{c}0.005 \\
(0.008)\end{array}$ & $\begin{array}{l}0.036 \\
-0.06\end{array}$ & $\begin{array}{l}-0.004 \\
(0.007)\end{array}$ & $\begin{array}{c}0.068 \\
(0.026)^{\star \star}\end{array}$ \\
\hline PAR & $\begin{array}{c}-0.194 \\
(0.053)^{\star \star \star}\end{array}$ & $\begin{array}{c}0.909 \\
(0.216)^{\star \star \star}\end{array}$ & $\begin{array}{c}-0.203 \\
(0.051)^{\star \star \star}\end{array}$ & $\begin{array}{c}0.557 \\
(0.197)^{\star \star \star}\end{array}$ & $\begin{array}{c}-0.199 \\
(0.050)^{\star \star \star}\end{array}$ & $\begin{array}{c}0.005 \\
(0.004)^{*}\end{array}$ & $\begin{array}{c}-0.229 \\
(0.054)^{\star \star \star}\end{array}$ & $\begin{array}{c}0.961 \\
(0.215)^{\star \star \star}\end{array}$ \\
\hline $\begin{array}{l}\text { Regional dummies } \\
\text { Time dummies }\end{array}$ & \multicolumn{2}{|c|}{ excluded } & \multicolumn{2}{|c|}{ excluded } & \multicolumn{2}{|c|}{ included } & \multicolumn{2}{|c|}{$\begin{array}{l}\text { excluded } \\
\text { excluded }\end{array}$} \\
\hline$n$ & \multicolumn{2}{|c|}{1,981} & \multicolumn{2}{|c|}{1,981} & \multicolumn{2}{|c|}{1,981} & \multicolumn{2}{|c|}{1,987} \\
\hline $\mathrm{R}^{2}$ (individual equations) & 0.08 & 0.11 & 0.20 & 0.27 & 0.22 & 0.27 & 0.05 & 0.10 \\
\hline $\mathrm{R}^{2}$ (increase wrt benchmark) & 0.023 & 0.005 & 0.027 & 0.009 & 0.026 & 0.009 & - & - \\
\hline $\begin{array}{l}\text { Breusch-Pagan } \\
\text { Joint F-test }\end{array}$ & \multicolumn{2}{|c|}{$49.624^{\star \star *}$} & \multicolumn{2}{|c|}{$74.213^{\star \star \star}$} & \multicolumn{2}{|c|}{$38.01^{\star \star \star}$} & - & $9^{\star \star \star}$ \\
\hline
\end{tabular}




\section{Table 3. Subsidy uncertainty measured by spread}

We jointly regress IRC and ALS on subsidy uncertainty and controls. We use the seemingly unrelated regressions (SUR) procedure. We use the spread of subsidy as a percentage of total assets instead of the standard deviation as a measure for subsidy uncertainty. The Breusch-Pagan test asserts the null hypothesis that the residuals of the separate regressions are uncorrelated. We also report a joint F-test for subsidy uncertainty that asserts the null hypothesis that the coefficients for subsidy uncertainty are jointly significant. $*, * *$, and $* * *$ denote statistical significance at $10 \%, 5 \%$, and $1 \%$ level, respectively.

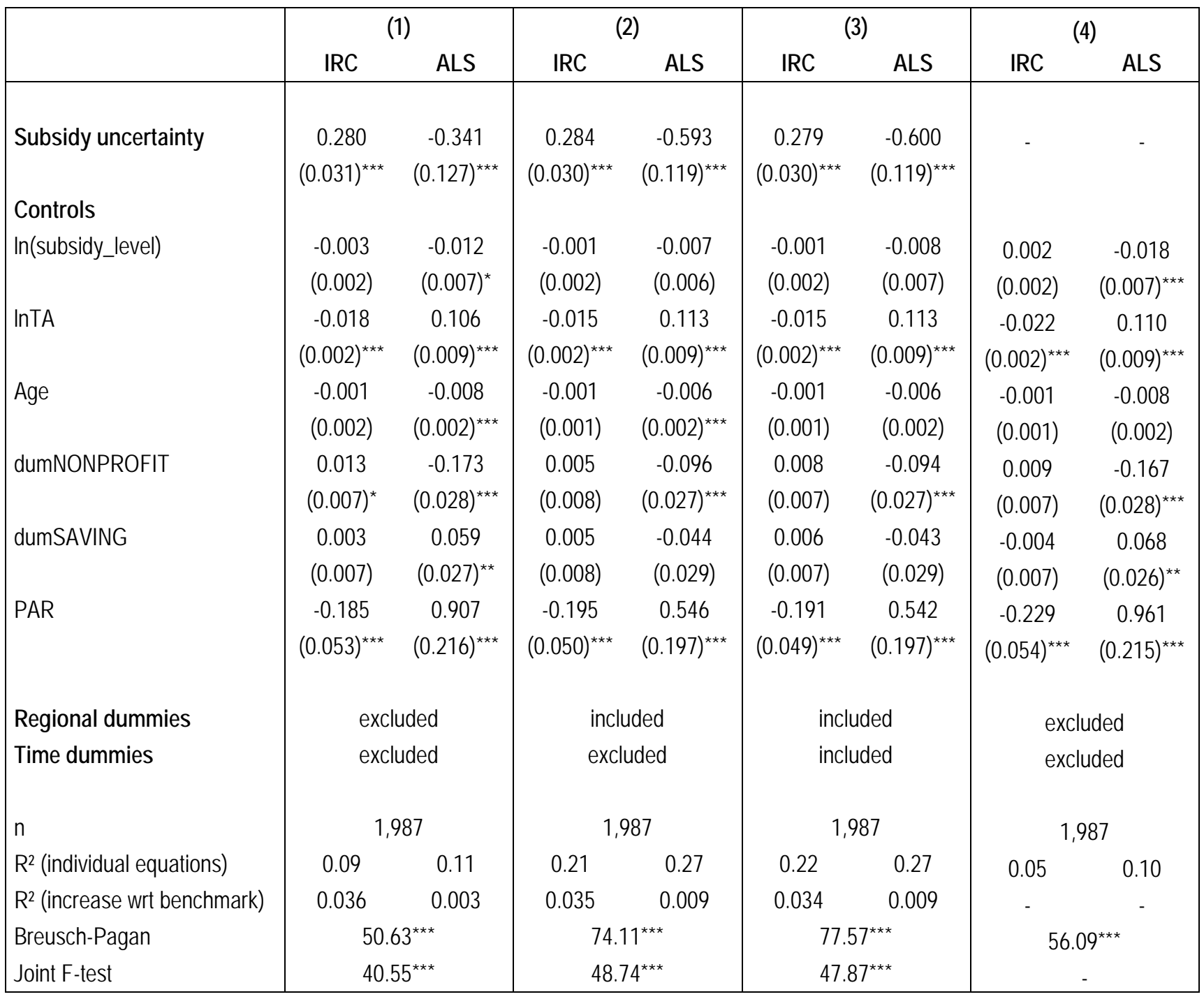




\section{Table 4. Subsample with 5-year data}

We jointly regress IRC and ALS on subsidy uncertainty and controls. We use the seemingly unrelated regressions (SUR) procedure. We use the subsample of MFIs for which we minimally 5-year data. The Breusch-Pagan test asserts the null hypothesis that the residuals of the separate regressions are uncorrelated. We also report a joint F-test for subsidy uncertainty that asserts the null hypothesis that the coefficients for subsidy uncertainty are jointly significant. *, ${ }^{* *}$, and $* * *$ denote statistical significance at $10 \%, 5 \%$, and $1 \%$ level, respectively.

\begin{tabular}{|c|c|c|c|c|c|c|c|c|}
\hline & \multicolumn{2}{|c|}{ (1) } & \multicolumn{2}{|c|}{ (2) } & \multicolumn{2}{|c|}{ (3) } & \multicolumn{2}{|c|}{ (4) } \\
\hline & IRC & ALS & IRC & ALS & IRC & ALS & IRC & ALS \\
\hline Subsidy uncertainty & $\begin{array}{c}0.545 \\
(0.081)^{\star \star \star}\end{array}$ & $\begin{array}{c}-0.867 \\
(0.336)^{\star \star}\end{array}$ & $\begin{array}{c}0.592 \\
(0.079)^{\star \star \star}\end{array}$ & $\begin{array}{l}-1.512^{\star \star \star} \\
(0.314)^{\star \star \star}\end{array}$ & $\begin{array}{c}0.596 \\
(0.078)^{\star \star \star}\end{array}$ & $\begin{array}{c}-1.500 \\
(0.314)^{\star \star \star}\end{array}$ & - & - \\
\hline Controls & & & & & & & & \\
\hline In(subsidy_level) & $\begin{array}{l}-0.002 \\
(0.002)\end{array}$ & $\begin{array}{c}-0.013 \\
(0.007)^{\star}\end{array}$ & $\begin{array}{l}-0.001 \\
(0.002)\end{array}$ & $\begin{array}{l}-0.008 \\
(0.007)\end{array}$ & $\begin{array}{l}-0.001 \\
(0.002)\end{array}$ & $\begin{array}{l}-0.009 \\
(0.007)\end{array}$ & $\begin{array}{c}0.002 \\
(0.002)\end{array}$ & $\begin{array}{c}-0.019 \\
(0.007)^{\star \star \star}\end{array}$ \\
\hline $\operatorname{lnTA}$ & $\begin{array}{c}-0.023 \\
(0.003)^{\star \star \star}\end{array}$ & $\begin{array}{c}0.110 \\
(0.011)^{\star \star \star}\end{array}$ & $\begin{array}{c}-0.018 \\
(0.002)^{\star \star \star}\end{array}$ & $\begin{array}{c}0.113 \\
(0.009)^{\star \star \star}\end{array}$ & $\begin{array}{c}-0.018 \\
(0.002)^{\star \star \star}\end{array}$ & $\begin{array}{c}0.114 \\
(0.009)^{\star \star \star}\end{array}$ & $\begin{array}{c}-0.027 \\
(0.003)^{\star \star \star}\end{array}$ & $\begin{array}{c}0.116 \\
(0.010)^{\star \star \star}\end{array}$ \\
\hline Age & $\begin{array}{c}0.001 \\
(0.001)\end{array}$ & $\begin{array}{c}-0.009 \\
(0.002)^{\star \star \star}\end{array}$ & $\begin{array}{l}-0.001 \\
(0.001)\end{array}$ & $\begin{array}{c}-0.007 \\
(0.002)^{\star *}\end{array}$ & $\begin{array}{l}-0.001 \\
(0.001)\end{array}$ & $\begin{array}{l}-0.006 \\
(0.002)\end{array}$ & $\begin{array}{l}-0.001 \\
(0.001)\end{array}$ & $\begin{array}{l}-0.009 \\
(0.002)\end{array}$ \\
\hline dumNONPROFIT & $\begin{array}{c}0.008 \\
(0.007)\end{array}$ & $\begin{array}{c}-0.159 \\
(0.029)^{\star \star \star}\end{array}$ & $\begin{array}{c}0.001 \\
(0.007)\end{array}$ & $\begin{array}{c}-0.067 \\
(0.028)^{\star \star}\end{array}$ & $\begin{array}{c}0.008 \\
(0.007)\end{array}$ & $\begin{array}{c}-0.064 \\
(0.028)^{\star \star}\end{array}$ & $\begin{array}{c}0.005 \\
(0.007)\end{array}$ & $\begin{array}{c}-0.155 \\
(0.029)^{\star \star \star}\end{array}$ \\
\hline dumSAVING & $\begin{array}{c}0.004 \\
(0.007)\end{array}$ & $\begin{array}{c}0.058 \\
(0.028)^{\star \star}\end{array}$ & $\begin{array}{c}0.005 \\
(0.008)\end{array}$ & $\begin{array}{l}-0.037 \\
(0.031)\end{array}$ & $\begin{array}{c}0.005 \\
(0.008)\end{array}$ & $\begin{array}{l}-0.036 \\
(0.031)\end{array}$ & $\begin{array}{l}-0.003 \\
(0.007)\end{array}$ & $\begin{array}{c}0.068 \\
(0.028)^{\star \star}\end{array}$ \\
\hline PAR & $\begin{array}{c}-0.226 \\
(0.056)^{\star \star \star}\end{array}$ & $\begin{array}{c}1.068 \\
(0.234)^{\star \star \star}\end{array}$ & $\begin{array}{c}-0.232 \\
(0.053)^{\star \star \star}\end{array}$ & $\begin{array}{c}0.687 \\
(0.212)^{\star \star \star}\end{array}$ & $\begin{array}{c}-0.230 \\
(0.053)^{\star \star \star}\end{array}$ & $\begin{array}{c}0.678 \\
(0.212)^{\star \star \star}\end{array}$ & $\begin{array}{c}-0.256 \\
(0.056)^{\star \star \star}\end{array}$ & $\begin{array}{c}1.115 \\
(0.234)^{\star \star \star}\end{array}$ \\
\hline $\begin{array}{l}\text { Regional dummies } \\
\text { Time dummies }\end{array}$ & $\begin{array}{l}\text { exc } \\
\text { exc }\end{array}$ & $\begin{array}{l}\text { ded } \\
\text { ded }\end{array}$ & $\begin{array}{l}\text { inc } \\
\text { exc }\end{array}$ & $\begin{array}{l}\text { ided } \\
\text { ided }\end{array}$ & $\begin{array}{l}\text { inc } \\
\text { inc }\end{array}$ & $\begin{array}{l}\text { ided } \\
\text { ided }\end{array}$ & $\begin{array}{l}\text { exc } \\
\text { exc }\end{array}$ & $\begin{array}{l}\text { ided } \\
\text { ided }\end{array}$ \\
\hline$n$ & & & & & & & & \\
\hline $\mathrm{R}^{2}$ (individual equations) & 0.10 & 0.11 & 0.21 & 0.29 & 0.23 & 0.28 & 0.07 & 0.10 \\
\hline $\mathrm{R}^{2}$ (increase wrt benchmark) & 0.023 & 0.003 & 0.025 & 0.009 & 0.025 & 0.009 & - & - \\
\hline $\begin{array}{l}\text { Breusch-Pagan } \\
\text { Joint F-test }\end{array}$ & $\begin{array}{l}37 \\
23\end{array}$ & & $\begin{array}{l}59 \\
34\end{array}$ & $\begin{array}{l}0^{\star \star \star} \\
3^{\star \star \star}\end{array}$ & $\begin{array}{l}61 \\
34\end{array}$ & $\begin{array}{l}5^{\star \star \star} \\
0^{\star \star \star}\end{array}$ & & $5^{\star \star \star}$ \\
\hline
\end{tabular}




\section{Table 5. Subsidy in terms of donated equity}

We jointly regress IRC and ALS on subsidy uncertainty and controls. We use the seemingly unrelated regressions (SUR) procedure. We use the standard deviation of donated equity as a percentage of total equity as a measure for subsidy uncertainty. The Breusch-Pagan test asserts the null hypothesis that the residuals of the separate regressions are uncorrelated. We also report a joint F-test for subsidy uncertainty that asserts the null hypothesis that the coefficients for subsidy uncertainty are jointly significant. $*$, **, and $* * *$ denote statistical significance at $10 \%, 5 \%$, and $1 \%$ level, respectively.

\begin{tabular}{|c|c|c|c|c|c|c|c|c|}
\hline & \multicolumn{2}{|c|}{ (1) } & \multicolumn{2}{|c|}{ (2) } & \multicolumn{2}{|c|}{ (3) } & \multicolumn{2}{|c|}{ (4) } \\
\hline & IRC & ALS & IRC & ALS & IRC & ALS & IRC & ALS \\
\hline sd (donated equity / equity) & $\begin{array}{c}0.071 \\
(0.024)^{\star \star \star}\end{array}$ & $\begin{array}{l}-0.140 \\
(0.105)\end{array}$ & $\begin{array}{c}0.079 \\
(0.024)^{\star \star \star}\end{array}$ & $\begin{array}{c}-0.345 \\
(0.097)^{\star \star \star}\end{array}$ & $\begin{array}{c}0.087 \\
(0.023)^{\star \star \star}\end{array}$ & $\begin{array}{c}-0.324 \\
(0.097)^{\star \star \star}\end{array}$ & - & - \\
\hline Controls & & & & & & & & \\
\hline donated equity / equity & $\begin{array}{c}-0.020 \\
(0.011)^{\star}\end{array}$ & $\begin{array}{c}-0.201 \\
(0.047)^{\star \star \star}\end{array}$ & $\begin{array}{l}-0.007 \\
(0.011)\end{array}$ & $\begin{array}{c}-0.168 \\
(0.045)^{\star \star \star}\end{array}$ & $\begin{array}{l}-0.014 \\
(0.010)^{*}\end{array}$ & $\begin{array}{c}-0.193 \\
(0.045)^{\star \star \star}\end{array}$ & $\begin{array}{l}-0.002 \\
(0.010)\end{array}$ & $\begin{array}{c}-0.232 \\
(0.041)^{\star \star \star}\end{array}$ \\
\hline InTA & $\begin{array}{c}-0.020 \\
(0.002)^{\star \star \star}\end{array}$ & $\begin{array}{c}0.092 \\
(0.009)^{\star \star \star}\end{array}$ & $\begin{array}{c}-0.017 \\
(0.002)^{\star \star \star}\end{array}$ & $\begin{array}{c}0.101 \\
(0.008)^{\star \star \star}\end{array}$ & $\begin{array}{c}-0.017 \\
(0.002)^{\star \star \star}\end{array}$ & $\begin{array}{c}0.101 \\
(0.008)^{\star \star \star}\end{array}$ & $\begin{array}{c}-0.017 \\
(0.002)^{\star \star *}\end{array}$ & $\begin{array}{c}0.103 \\
(0.008)^{\star \star \star}\end{array}$ \\
\hline Age & $\begin{array}{c}0.001 \\
(0.001)\end{array}$ & $\begin{array}{c}-0.007 \\
(0.002)^{\star \star \star}\end{array}$ & $\begin{array}{l}-0.002 \\
(0.001)\end{array}$ & $\begin{array}{c}-0.004 \\
(0.002)^{\star \star}\end{array}$ & $\begin{array}{l}-0.001 \\
(0.003)\end{array}$ & $\begin{array}{l}-0.003 \\
(0.002)\end{array}$ & $\begin{array}{l}-0.001 \\
(0.001)\end{array}$ & $\begin{array}{l}-0.003 \\
(0.002)\end{array}$ \\
\hline dumNONPROFIT & $\begin{array}{l}0.001 \\
(0.006)\end{array}$ & $\begin{array}{c}-0.147 \\
(0.027)^{\star \star \star}\end{array}$ & $\begin{array}{l}-0.009 \\
(0.006)\end{array}$ & $\begin{array}{c}-0.081 \\
(0.026)^{\star \star \star}\end{array}$ & $\begin{array}{l}-0.005 \\
(0.006)\end{array}$ & $\begin{array}{c}-0.067 \\
(0.026)^{\star \star}\end{array}$ & $\begin{array}{l}-0.002 \\
(0.006)\end{array}$ & $\begin{array}{c}-0.060 \\
(0.0262)^{\star \star}\end{array}$ \\
\hline dumSAVING & $\begin{array}{l}-0.003 \\
(0.006)\end{array}$ & $\begin{array}{c}0.065 \\
(0.025)^{\star}\end{array}$ & $\begin{array}{c}0.003 \\
(0.007)\end{array}$ & $\begin{array}{l}-0.011 \\
(0.028)\end{array}$ & $\begin{array}{c}0.004 \\
(0.006)\end{array}$ & $\begin{array}{l}-0.012 \\
(0.027)\end{array}$ & $\begin{array}{c}0.003 \\
(0.007)\end{array}$ & $\begin{array}{l}-0.007 \\
(0.027)\end{array}$ \\
\hline PAR & $\begin{array}{c}-0.190 \\
(0.052)^{\star \star \star}\end{array}$ & $\begin{array}{c}0.959 \\
(0.224)^{\star \star \star}\end{array}$ & $\begin{array}{c}-0.207 \\
(0.049)^{\star \star \star}\end{array}$ & $\begin{array}{c}0.662 \\
(0.206)^{\star \star \star}\end{array}$ & $\begin{array}{c}-0.211 \\
(0.049)^{\star \star \star}\end{array}$ & $\begin{array}{c}0.634 \\
(0.206)^{\star \star \star}\end{array}$ & $\begin{array}{c}-0.217 \\
(0.048)^{\star \star \star}\end{array}$ & $\begin{array}{c}0.629 \\
(0.201)^{\star \star \star}\end{array}$ \\
\hline $\begin{array}{l}\text { Regional dummies } \\
\text { Time dummies }\end{array}$ & & $\begin{array}{l}\text { ded } \\
\text { ded }\end{array}$ & & $\begin{array}{l}\text { ded } \\
\text { ded }\end{array}$ & & & $\begin{array}{l}\text { exc } \\
\text { exc }\end{array}$ & $\begin{array}{l}\text { Ided } \\
\text { Ided }\end{array}$ \\
\hline$n$ & & & & & & & & \\
\hline $\mathrm{R}^{2}$ (individual equations) & 0.06 & 0.11 & 0.16 & 0.26 & 0.19 & 0.26 & 0.18 & 0.25 \\
\hline $\mathrm{R}^{2}$ (increase wrt benchmark) & 0.005 & 0.002 & 0.003 & 0.006 & 0.002 & 0.006 & - & - \\
\hline $\begin{array}{l}\text { Breusch-Pagan } \\
\text { Joint F-test }\end{array}$ & $\begin{array}{r}100 \\
4 .\end{array}$ & $\begin{array}{l}1^{\star \star *} \\
7 \star \star\end{array}$ & $\begin{array}{r}120 \\
9 .\end{array}$ & $5^{\star \star \star *}$ & $\begin{array}{r}134 \\
10\end{array}$ & $4^{\star \star \star \star}$ & & $17^{* \star *}$ \\
\hline
\end{tabular}




\section{Table 6. Downside deviation}

We jointly regress IRC and ALS on subsidy uncertainty and controls. We use the seemingly unrelated regressions (SUR) procedure. We use the calculated downsize deviation as a measure for subsidy uncertainty. The Breusch-Pagan test asserts the null hypothesis that the residuals of the separate regressions are uncorrelated. We also report a joint F-test for subsidy uncertainty that asserts the null hypothesis that the coefficients for subsidy uncertainty are jointly significant. *, **, and *** denote statistical significance at $10 \%$, $5 \%$, and $1 \%$ level, respectively.

\begin{tabular}{|c|c|c|c|c|c|c|}
\hline & \multicolumn{2}{|c|}{ (1) } & \multicolumn{2}{|c|}{ (2) } & \multicolumn{2}{|c|}{ (3) } \\
\hline & IRC & ALS & IRC & ALS & IRC & ALS \\
\hline \multirow[t]{2}{*}{ downsize deviation } & 0.785 & -1.696 & 0.905 & -2.501 & 0.968 & -2.453 \\
\hline & $(0.175)^{\star \star \star}$ & $(0.702)^{\star \star}$ & $(0.167)^{\star \star \star}$ & $(0.647)^{\star \star \star}$ & $(0.166)^{\star \star \star}$ & $(0.652)^{\star \star \star}$ \\
\hline \multicolumn{7}{|l|}{ Controls } \\
\hline \multirow[t]{2}{*}{ In(donations) } & -0.001 & -0.012 & 0.001 & -0.007 & -0.001 & -0.007 \\
\hline & $(0.002)$ & $(0.007)^{\star}$ & $(0.002)$ & $(0.007)$ & $(0.001)$ & $(0.007)$ \\
\hline \multirow[t]{2}{*}{$\operatorname{lnTA}$} & -0.017 & 0.102 & -0.013 & 0.108 & -0.014 & 0.108 \\
\hline & $(0.003)^{\star \star \star}$ & $(0.010)^{\star \star \star}$ & $(0.002)^{\star \star \star}$ & $(0.009)^{\star \star \star}$ & $(0.002)^{\star \star \star}$ & $(0.009)^{\star \star \star}$ \\
\hline \multirow[t]{2}{*}{ Age } & -0.001 & -0.008 & -0.001 & -0.006 & -0.001 & -0.006 \\
\hline & $(0.001)$ & $(0.002)^{\star \star \star}$ & $(0.001)$ & $(0.002)^{\star \star \star}$ & $(0.001)$ & $(0.002)^{\star \star \star}$ \\
\hline \multirow[t]{2}{*}{ dumNONPROFIT } & 0.011 & -0.171 & 0.003 & -0.094 & 0.007 & -0.094 \\
\hline & $(0.007)$ & $(0.028)^{\star \star \star}$ & $(0.007)$ & $(0.027)^{\star \star \star}$ & $(0.007)$ & $(0.027)^{\star \star \star}$ \\
\hline \multirow[t]{2}{*}{ dumSAVING } & -0.002 & 0.063 & -0.001 & -0.034 & 0.001 & -0.033 \\
\hline & $(0.007)$ & $(0.027)^{\star \star}$ & $(0.007)$ & $(0.029)$ & $(0.008)$ & $(0.0295)$ \\
\hline \multirow[t]{2}{*}{ PAR } & -0.213 & 0.924 & -0.219 & 0.586 & -0.214 & 0.588 \\
\hline & $(0.038)^{\star \star \star}$ & $(0.215)^{\star \star \star}$ & $(0.051)^{\star \star \star}$ & $(0.197)^{\star \star \star}$ & $(0.051)^{\star \star \star}$ & $(0.198)^{\star \star \star}$ \\
\hline Regional dummies & \multicolumn{2}{|c|}{ excluded } & \multicolumn{2}{|c|}{ included } & \multicolumn{2}{|c|}{ included } \\
\hline Time dummies & \multicolumn{2}{|c|}{ excluded } & \multicolumn{2}{|c|}{ excluded } & \multicolumn{2}{|c|}{ included } \\
\hline $\mathrm{n}$ & \multicolumn{2}{|c|}{1,981} & \multicolumn{2}{|c|}{1,981} & \multicolumn{2}{|c|}{1,981} \\
\hline $\mathrm{R}^{2}$ (individual equations) & 0.07 & 0.11 & 0.19 & 0.27 & 0.21 & 0.27 \\
\hline $\mathrm{R}^{2}$ (increase wrt benchmark) & 0.010 & 0.004 & 0.012 & 0.006 & 0.014 & 0.006 \\
\hline Breusch-Pagan & \multicolumn{2}{|c|}{$51.67^{\star \star \star}$} & \multicolumn{2}{|c|}{$79.65^{\star \star \star}$} & \multicolumn{2}{|c|}{$84.04^{\star \star \star}$} \\
\hline Joint F-test & \multicolumn{2}{|c|}{$11.44^{\star \star \star}$} & \multicolumn{2}{|c|}{$18.66^{\star \star \star}$} & \multicolumn{2}{|c|}{$20.42^{\star \star \star}$} \\
\hline
\end{tabular}




\section{Appendix 1. Countries and status}

We list the number of MFIs per country and different MFI-types in each country.

\begin{tabular}{|c|c|c|c|c|c|c|}
\hline country & \# MFIs & \#NGOs & \#COOPS & \#banks & \#NBFI & \#otherlunknown \\
\hline Afghanistan & 15 & 5 & 1 & 1 & 8 & 0 \\
\hline Albania & 6 & 0 & 1 & 1 & 4 & 0 \\
\hline Angola & 1 & 0 & 0 & 0 & 1 & 0 \\
\hline Argentina & 13 & 9 & 0 & 0 & 3 & 1 \\
\hline Armenia & 7 & 1 & 0 & 1 & 5 & 0 \\
\hline Azerbaijan & 12 & 0 & 1 & 0 & 11 & 0 \\
\hline Bangladesh & 53 & 52 & 1 & 0 & 0 & 0 \\
\hline Benin & 13 & 8 & 4 & 0 & 1 & 0 \\
\hline Bolivia & 16 & 12 & 0 & 1 & 3 & 0 \\
\hline Bosnia and Herzegovina & 11 & 0 & 0 & 0 & 11 & 0 \\
\hline Brazil & 11 & 10 & 0 & 1 & 0 & 0 \\
\hline Bulgaria & 4 & 0 & 1 & 0 & 3 & 0 \\
\hline Burkina Faso & 8 & 2 & 4 & 0 & 1 & 1 \\
\hline Burundi & 6 & 1 & 3 & 0 & 2 & 0 \\
\hline Cambodia & 13 & 1 & 0 & 1 & 10 & 1 \\
\hline Cameroon & 12 & 3 & 6 & 0 & 3 & 0 \\
\hline Central African Republic & 1 & 0 & 1 & 0 & 0 & 0 \\
\hline Chad & 3 & 1 & 1 & 0 & 1 & 0 \\
\hline Chile & 4 & 2 & 0 & 2 & 0 & 0 \\
\hline China, People's Republic of & 9 & 4 & 0 & 1 & 1 & 3 \\
\hline Colombia & 19 & 17 & 0 & 0 & 1 & 1 \\
\hline Congo, Democratic Republic of the & 10 & 3 & 3 & 1 & 2 & 1 \\
\hline Congo, Republic of the & 3 & 1 & 2 & 0 & 0 & 0 \\
\hline Costa Rica & 5 & 4 & 0 & 0 & 1 & 0 \\
\hline Cote d'Ivoire (Ivory Coast) & 5 & 0 & 4 & 0 & 1 & 0 \\
\hline Croatia & 2 & 0 & 2 & 0 & 0 & 0 \\
\hline Dominican Republic & 8 & 5 & 0 & 1 & 0 & 2 \\
\hline East Timor & 2 & 2 & 0 & 0 & 0 & 0 \\
\hline Ecuador & 23 & 11 & 10 & 2 & 0 & 0 \\
\hline Egypt & 15 & 14 & 0 & 1 & 0 & 0 \\
\hline El Salvador & 11 & 7 & 0 & 0 & 4 & 0 \\
\hline Ethiopia & 21 & 0 & 0 & 0 & 21 & 0 \\
\hline Gabon & 1 & 0 & 0 & 0 & 1 & 0 \\
\hline Gambia, The & 2 & 0 & 0 & 0 & 2 & 0 \\
\hline Georgia & 9 & 1 & 0 & 2 & 6 & 0 \\
\hline Ghana & 16 & 11 & 0 & 0 & 2 & 3 \\
\hline
\end{tabular}




\begin{tabular}{|c|c|c|c|c|c|}
\hline Guatemala & 19 & 19 & 0 & 0 & 0 \\
\hline Guinea & 4 & 1 & 1 & 1 & 1 \\
\hline Guinea-Bissau & 2 & 0 & 2 & 0 & 0 \\
\hline Haiti & 7 & 4 & 0 & 0 & 3 \\
\hline Honduras & 14 & 5 & 0 & 2 & 7 \\
\hline India & 86 & 52 & 7 & 1 & 22 \\
\hline Indonesia & 9 & 5 & 2 & 0 & 0 \\
\hline Iraq & 11 & 11 & 0 & 0 & 0 \\
\hline Jordan & 6 & 1 & 0 & 0 & 4 \\
\hline Kazakhstan & 11 & 1 & 0 & 10 & 0 \\
\hline Kenya & 19 & 8 & 1 & 2 & 8 \\
\hline Kosovo & 8 & 6 & 0 & 0 & 2 \\
\hline Kyrgyzstan & 10 & 1 & 1 & 1 & 7 \\
\hline Laos & 1 & 0 & 0 & 0 & 1 \\
\hline Lebanon & 3 & 2 & 0 & 0 & 1 \\
\hline Liberia & 2 & 1 & 0 & 0 & 1 \\
\hline Macedonia & 2 & 1 & 1 & 0 & 0 \\
\hline Madagascar & 11 & 0 & 8 & 0 & 3 \\
\hline Malawi & 7 & 4 & 1 & 1 & 1 \\
\hline Malaysia & 1 & 1 & 0 & 0 & 0 \\
\hline Mali & 19 & 7 & 10 & 0 & 1 \\
\hline Mexico & 27 & 7 & 1 & 1 & 18 \\
\hline Moldova & 2 & 0 & 0 & 0 & 2 \\
\hline Mongolia & 2 & 0 & 0 & 1 & 1 \\
\hline Montenegro & 1 & 0 & 0 & 1 & 0 \\
\hline Morocco & 10 & 10 & 0 & 0 & 0 \\
\hline Mozambique & 8 & 5 & 0 & 2 & 1 \\
\hline Namibia & 1 & 1 & 0 & 0 & 0 \\
\hline Nepal & 20 & 7 & 3 & 2 & 7 \\
\hline Nicaragua & 23 & 18 & 3 & 1 & 1 \\
\hline Niger & 7 & 0 & 6 & 0 & 1 \\
\hline Nigeria & 8 & 3 & 0 & 2 & 3 \\
\hline Pakistan & 24 & 17 & 0 & 1 & 5 \\
\hline Palestine & 8 & 4 & 0 & 1 & 2 \\
\hline Panama & 2 & 1 & 1 & 0 & 0 \\
\hline Papua New Guinea & 2 & 0 & 0 & 0 & 1 \\
\hline Paraguay & 2 & 2 & 0 & 0 & 0 \\
\hline Peru & 20 & 12 & 3 & 0 & 5 \\
\hline Philippines & 31 & 23 & 4 & 0 & 0 \\
\hline Poland & 3 & 1 & 0 & 0 & 2 \\
\hline Romania & 5 & 1 & 0 & 0 & 4 \\
\hline Russia & 77 & 3 & 64 & 1 & 7 \\
\hline Rwanda & 6 & 0 & 1 & 0 & 5 \\
\hline
\end{tabular}




\begin{tabular}{|c|c|c|c|c|c|c|}
\hline Saint Lucia & 1 & 0 & 1 & 0 & 0 & 0 \\
\hline Samoa & 1 & 1 & 0 & 0 & 0 & 0 \\
\hline Senegal & 16 & 1 & 15 & 0 & 0 & 0 \\
\hline Serbia & 2 & 1 & 0 & 0 & 1 & 0 \\
\hline Sierra Leone & 6 & 4 & 0 & 0 & 1 & 1 \\
\hline Slovakia & 1 & 1 & 0 & 0 & 0 & 0 \\
\hline South Africa & 9 & 8 & 0 & 0 & 1 & 0 \\
\hline Sri Lanka & 15 & 7 & 0 & 0 & 8 & 0 \\
\hline Sudan & 4 & 2 & 0 & 0 & 2 & 0 \\
\hline Tajikistan & 23 & 1 & 0 & 2 & 20 & 0 \\
\hline Tanzania & 10 & 7 & 0 & 1 & 2 & 0 \\
\hline Thailand & 3 & 1 & 0 & 0 & 1 & 1 \\
\hline Togo & 13 & 6 & 7 & 0 & 0 & 0 \\
\hline Tonga & 1 & 0 & 0 & 0 & 0 & 1 \\
\hline Trinidad and Tobago & 2 & 1 & 0 & 0 & 1 & 0 \\
\hline Tunisia & 1 & 1 & 0 & 0 & 0 & 0 \\
\hline Turkey & 2 & 2 & 0 & 0 & 0 & 0 \\
\hline Uganda & 16 & 4 & 4 & 2 & 5 & 1 \\
\hline Ukraine & 1 & 0 & 0 & 0 & 1 & 0 \\
\hline Uruguay & 1 & 0 & 0 & 0 & 1 & 0 \\
\hline Uzbekistan & 7 & 6 & 1 & 0 & 0 & 0 \\
\hline Vietnam & 13 & 11 & 0 & 1 & 1 & 0 \\
\hline Yemen & 6 & 5 & 0 & 0 & 1 & 0 \\
\hline Zambia & 7 & 4 & 0 & 0 & 3 & 0 \\
\hline Zimbabwe & 3 & 2 & 0 & 0 & 1 & 0 \\
\hline Unknown & 76 & 0 & 0 & 0 & 0 & 76 \\
\hline TOTAL & 1151 & 508 & 193 & 53 & 286 & 111 \\
\hline
\end{tabular}


${ }^{1}$ See D'Espallier et al. (2013a). We henceforth refer to all institutional sources of subsidies to microfinance as “donors”.

2 More and more donors audit the financial accounts of the institutions benefitting from subsidies (Beisland and Mersland, forthcoming). They also produce rating reports (Beisland and Mersland, 2012; Gutiérrez-Nieto et al., 2012).

${ }^{3}$ Appendix 1 lists the number of MFIs of each type in each country.

${ }^{4}$ The average operational sustainability ratio is $115 \%$ in the MBB (2008) and $107 \%$ in our database. The average number of borrowers is 11,041 in the MBB (2008) and 23,689 in our database. The average nominal yield is 30\% in the MBB (2008) and 24\% in our database. Last, average staff productivity proxied by number of borrowers per staff member is 112 in the MBB (2008) and 123 in our database.

${ }^{5}$ Roberts (2013) uses the annual effective rate to measure the microcredit interest rate. The annual effective rate is more sophisticated than portfolio yield since it includes other components, such as compulsory savings, fees, loan products with different terms, and delinquency rates (Rosenberg et al., 2013). However, data limitations prevented us from computing annual effective rates.

6 We report the coefficient on dumNONPROFIT to account for the difference in ALS and IRC between NGOs/coops and for-profit MFIs. The results are unchanged when all but one detailed status dummies NGO, coop, NBFI, BANK are taken up as controls.

${ }^{7}$ Regional dummies are based upon classifying the country in which the MFI is active into the five main world regions: Middle East and North Africa (MENA), Eastern Europe and Central Asia (ECA), Latin America and the Caribbean (LAC), Sub-Saharan Africa (AFR), and South-Asia (ASIA).

8 Specifically, we consider the lending rate and the relative change in development aid because these variables might influence the interest rates charged. 